\title{
Storytelling as a Cultural Practice and Life Form
}

Telling always binds one thing to another. We want a coherent world, not one in bits and pieces. (Hustvedt, 2008, p. 276)

According to Roland Barthes, "narrative begins with the very history of humanity" (1988, p. 95). Narrative is a cross-cultural phenomenon (Meuter, 1995, p. 173) that has always been present "in all periods, all places, all societies” (Barthes, 1988, p. 95). In Ludwig Wittgenstein's words, "recounting ... [is] as much a part of our natural history as walking, eating, drinking, playing" (1953, p. 12e) and as such it is one of the fundamental activities of life. Narratives and stories already exist before we arrive on the scene; we are born into a world of narrations which make up the "unexamined ground of everything given in [our] experience" (Schutz \& Luckmann, 1974, p. 4).

Schutz and Luckmann posit that narrations emerge because "the world is already given to [us] for [our] explication" (1974, p. 6), motivated by the necessity of comprehending the world "in order to be able to act in it" (1974, p. 6). As used by Schutz and Luckmann (1974, pp. 3, 15), narrations represent meaning-contexts or life-worlds, which consist of an aggregation of experiences, orientations, principles, values, and norms which have been and always will be related to each other by subjects in such a way that they function as the foundation of meaning for thinking and doing. When telling our stories, we intertwine the various elements of meaning, emphasizing or relativizing them in a never-ending process. 
From a historical perspective, meaning-contexts represent a continuum as what we explicate is but an explication of what has been explicated in the past. We trust that the world we are familiar with will continue to be familiar and that the "stock of knowledge obtained from [our] fellow-men and formed from [our] own experiences will continue to preserve its fundamental validity" $(1974$, p. 7). "And so forth" $(1974$, p. 7$)$ is an "essential aspect of thinking" according to Schutz and Luckmann (1974, p. 8).

At this point I would like to elaborate my understanding of the notions of narrative (Erzäblung), narration (Narration), and storytelling (Erzäblen). Just like the concept of narration, a narrative should indicate an active process whereas storytelling relates to the narrative act itself (see also Mahne, 2006, pp. 12-13). In storytelling, the "how" is dominant; in narrative and narration alike, the "how" and the "what" are closely connected. Narratives or narrations combine various episodes, points in time, and places, linking them to each other to create a meaningful relationship. They consist of elements of meaning which, when combined, result in an overall meaning which is not, however, inherently definitive. Narrations or narratives can change, subject to time and space. I do not regard storytelling as either a purely rational action or a purely descriptive activity; it also includes emotions and moods as well as reflections and interpretations.

As already mentioned, we are born into a world of stories which are told to us and which we tell to Others. In and through our narratives, we make the world our own; we situate ourselves in this world and tell Others in it about ourselves. Narrative acts as a means with which to understand the world; storytelling acts as a means of conveying that understanding and-a point I will return to later-as an instrument for configuring the world.

A prerequisite for telling a story is the ability to use a language; language is the vehicle of narrative. But not only oral and written verbal languages take on this function; as Roland Barthes would have it, it can also be performed "by image, fixed or moving, by gesture, and by the organized mixture of all these substances" (1988, p. 95). Accordingly, narratives can be found everywhere and at any time: in everyday gossip, in film, in comics, on billboards, on the bodies and faces of individuals, in architecture, in the internet, in politicians' speeches, in newspapers, and in academic texts. Even Nature can tell stories, as seen in the Brothers Grimm's German Dictionary, in which the following quotations from the Old Testament are used in the entry for erzäblen: "The fishes of the sea shall declare unto thee" and "The heavens declare the glory of God" (Grimm \& Grimm, 1862/1984, p. 1077). 
Things can become the vehicle of narratives, but the narrative itself always remains immaterial in nature, composed as it is of symbols and meanings. Susanne Langer distinguishes between discursive and presentational symbols. Verbal language is basically discursive in Langer's view (1957, p. 96). The individual elements of verbal language are units with independent meaning which, to use Langer's metaphor, are like "pieces of clothing ... strung side by side on the clothesline" (1957, p. 81). The logic of discursivity is such that "only thoughts which can be arranged in this peculiar order can be spoken at all; any idea which does not lend itself to this 'projection' is ineffable, incommunicable by means of words" (1957, pp. 81-82).

Although presentational symbols also consist of units which are components of a narration, these units do not have independent meanings (Langer, 1957, p. 94). Light and dark areas in a photograph, for instance, which can be taken as an example of presentational symbolism, do not convey meaning by themselves (1957, p. 94). But in combination with other elements, they have an effect, resulting in an image which is revealed to the viewer all at once and not gradually $(1957$, p. 94).

Whether we make use of discursive or presentational symbolism for our narratives, we draw on existing symbols, as already mentioned; otherwise we would be unintelligible. But we do not simply adapt these symbols; we modify and mould them. As Alfred Lorenzer puts it, we join in interaction games making use of an existing system of symbols. With respect to presentational symbols, we develop sensory-symbolic interaction forms; with respect to discursive symbols, we develop linguistic-symbolic interaction forms (1981, pp. 159ff.). In the sensory-symbolic interaction forms, we are closer to emotions and bodily processes while the linguistic-symbolic interaction forms force us to come to grips with the world in a rational and reflexive manner. In the process of storytelling, we combine these interaction forms, storytelling thus becoming the instrument with which to mould our system of symbols.

According to Wolfgang Kraus, narrative psychology starts with the premise that "we configure our lives and our relationship to the world as narrative and that we also engage in our daily interactions and the organization of what we have experienced with the help of an ongoing narrative" (2000, p. 4). Our entire lives take place in narrative or narration, if we ascribe to Barbara Hardy's view that

${ }^{1}$ All quotations from German publications were translated into English for this book. 
we dream in narrative, daydream in narrative, remember, anticipate, hope, despair, believe, doubt, plan, revise, criticize, construct, gossip, learn, hate, and love by narrative. In order really to live, we make up stories about ourselves and others, about the personal as well as the social past and future. $(1968$, p. 5$)$

By telling stories and through our narratives, we reveal the manner in which we live, if Hardy is right; in this sense, storytelling generates life forms.

Narrative life forms are intersubjective life forms; they are connected to existing systems of symbols and continue to develop through the negotiation of meanings in a social context. One result of this negotiation is shared meaning-contexts, which are the foundations of culture. A concept of culture which is guided by life forms integrates everyday culture (Welsch, 2001, p. 256). Here culture should be understood as communally developed and shared systems of meaning and symbols as well as ways of living and working together, in line with Jerome Bruner (1990, p. 11). In fact, the notion of culture did not crystalize until the end of the seventeenth century (Welsch, 2001, p. 255). Even then, Samuel von Pufendorf, a professor of natural law, was interested in the constitutive dimension of culture, defining it in his (1684) tome Of the Law of Nature and Nations as "the totality of those activities by which men structure their lives as humans - in contrast to beasts merely eking out their existence" (quoted in Welsch, 2001, p. 255). The constitutive element would be inconceivable without narrative interpretation and the negotiation of meanings in the interaction of various narratives as it implies variation and change. Culture is a narrative which does not only represent norms, as Bruner puts it, but which also allows for interpretative leeway so that deviations from the norm still make sense (1990, p. 47). In other words, narrative "specializes in the forging of links between the exceptional and the ordinary" (1990, p. 47) such that "the viability of a culture inheres in its capacity for resolving conflicts, for explicating differences and renegotiating communal meanings" (1990, p. 47).

Viewing culture as a narrative means characterizing it as being the creation of human subjects. But culture is also prescriptive, providing us as it does with a script, the vocabulary of which "set[s] boundaries and give[s] direction to future creative effort" for our thoughts, perceptions, and interpretations (Hutton, 1988, p. 122). As cultural practices, narrative life forms produce a habitus in Pierre Bourdieu's terms. They harbour 
dispositions which are "predisposed to function as structuring structures, that is, as principles which generate and organize practices and representations" (1980/1990, p. 53). The babitus of narrative life forms points to the effective presence of the past conditions which generated them (1980/1990, p. 56). But their efficacy is relative; the past permits, opens up, prevents, disrupts, and facilitates, but it is not deterministic, at least not when reflexive reference is made to it. Bourdieu describes the dialectic effect of the past on the habitus as follows: "The habitus is an infinite capacity for generating products-thoughts, perceptions, expressions, and actions-whose limits are set by the historically and socially situated conditions of its production" (1980/1990, p. 55). In this respect, narratives exist in the realm between freedom and determinism.

The potential for narratives to cross borders suggests that cultures may open up as a result. What happens when narratives intersect which come from different parts of the world and which draw on different cultural traditions? In the light of global communication networks, this question is particularly relevant at present. Will these cultures prove to be a "closed sphere" (Welsch, 2001, p. 258) in tune with the classical model of monolithic cultures associated with Johann Gottfried Herder? Herder wrote that "each nation has its center of happiness in itself, like every sphere its center of gravity!" (1774/2002, p. 297). As individual nations turn towards their centres, this makes them "more blooming in their kind, more passionate and hence also happier in their inclinations and purposes" (1774/2002, p. 297). These comments could be interpreted as a plea in favour of the homogenization of culture. But Herder is not consistent either: Just a few pages later, he points out how individual cultures feed on other cultures, writing "the Egyptian was not able to exist without the Oriental, the Greek built upon them, the Roman raised himself onto the back of the whole world-truly progress, progressive development" (1774/2002, p. 299). Questions relating to the criss-crossing of cultural practices as a consequence of and precondition for storytelling will be picked up on and discussed time and again in the pages of this book.

Narratives take place in the present, feed on the past, and point to the future. They encompass both individual and collective elements. They constitute space and conquer spaces. Time and space create contexts for storytelling in more ways than one. As cultural practices and life forms in time and space, storytelling gains in importance for the I and the You in equal measure. The following sections will discuss the contexts and functions of storytelling in more detail. 


\subsection{Contexts of Storytelling}

The notion of context is used here along two dimensions, firstly in its meaning as a setting or framework for narratives and secondly in its meaning as a content-related and structural relationship for narratives.

\subsubsection{Time}

Storytelling forges links with the phenomenon of time as Paul Ricœur illustrated in the second volume of Time and Narrative (1985). Ricour made this point in connection with literature and history as well as with everyday stories (Meuter, 1995, p. 123). In this section, time is discussed as a point of reference for and the product of storytelling, which then becomes a product for framing further narratives. Above and beyond that, the time of the narrative itself is examined in which it takes on a cohesive role.

\subsubsection{Time as a Point of Reference for Storytelling}

According to Paul Ricour, narratives have their own system of tenses, namely "tenses that are included, others that are excluded" (1985, p. 63). Stories always relate to the past and never to the present or the future-an assumption he makes on the grounds that in the moment in which something is recounted, that something has already happened. Stories include three past tenses: "the aorist (or preterite), the imperfect, and the pluperfect” (1985, p. 63).

In as much as storytelling makes recourse to experiences, the reference to the past is a foregone conclusion. A narrative is produced by combining heterogeneous happenings from the past into temporal units, thus making it possible to assign them to a particular point in time. This is a process of configuration as telling stories involves selecting, accentuating, relativizing, and emphasizing. In this respect, Norbert Meuter is right when he sees storytelling as being a process of selection, the purpose of which is to reduce complexity $(1995$, p. 133). Meuter speaks of a "synthesis of the heterogeneous," a complex interplay of intentional events and intentionally contingent events (1995, p. 128).

Memory is the faculty which enables us to narrate events from the past (Assmann, 1991, p. 185). Narrative recall is the starting point for becoming aware of something which breaches, structures, and records the flow of experience (1991, p. 185). I emerge from the sphere of pure experience 
and make use of language to label what I can remember. Thanks to the "shaft of attention" (Schutz, 1932/1967, p. 73) of storytelling, lived experiences which are struck by this beam preserve a fixed past. The fluid nature of the stream of experiences acquires fixed elements (Assmann, 1991, p. 185).

For Ricœur, as already mentioned, the present and the future are not points of reference for telling stories. From Alfred Schutz's perspective, they certainly can be. Schutz assumes, namely, that lived experience can be assigned a different meaning "depending on the temporal distance from which it is remembered and looked back upon" (1932/1967, p. 74). The actual meaning of lived experience is therefore extrapolated from the particular "Here-Now-and-Thus" (1932/1967, p. 73). That means that the present puts its mark on lived experiences; even more so, as the "HereNow-and-Thus" is subject to modification, the meaning of a lived experience can also change. Thus the ossification of lived experience in the memory is not permanent: It can be subject to modification or even liquidation in the particular "Here-Now-and-Thus" of the "reflective glance" (1932/1967, p. 74). Admittedly, when we consider the habitus of narrative, the changes in meaning which the past undergoes are not arbitrary but subject to the limitations of the forms of habitus, which, as already constituted dispositions, become the foundation for later evaluations and judgements (Bourdieu, 1980/1990, pp. 53ff.).

Following Alfred Schutz's line of argument, the future can also be a reference point for telling stories. Schutz takes the view that every "HereNow-and-Thus" experience has a before and an after "with horizons opening equally into the past and the future" (1932/1967, p. 75). Experiences are not discrete; rather they are embedded in a stream of experiences which takes us to a point somewhere ahead of us. Our reflexive attention to these experiences necessarily anticipates every coming-tobe for it is located in these experiences. It takes shape in the wishes, predictions, and visions which we voice.

Narratives are connected to various time horizons, something which narrators clarify with the help of connectors like and, and then, and because as well as verbs like begin, stop, evoke, and trigger (Meuter, 1995, p. 133) or the subjunctive mood in German (ich käme, ich wïrde kommen, both translated as "I would come"). Heterogeneous events from the past and potential events in the future are placed in a temporal order from the perspective of the "Here-Now-and-Thus" (Schutz, 1932/1967, p. 73), resulting in a well-rounded story for the narrator, or a meaning-context 
on which the narrator can build, thus opening up a wealth of opportunities for action.

\subsubsection{Time and Narrative}

Time is not only a point of reference for telling stories; storytelling itself has a temporal structure as it passes through a "certain passage of time" (Waldenfels, 2001, p. 19). Every narrative has a beginning and an end, even if only imaginary, feared, or desired. The passage of time between the beginning and the end is accompanied by questions as to the whence on the one hand and the whither on the other in an attempt to place the narrative in a meaning-context. The whence and whither permeate every aspect of our lives, affecting them as a whole. In his introduction, Wilmes asks "Where do I come from? Where am I going?" (Mullican, 2011, p. 14), questions which relate to the entire life of American conceptual artist Matt Mullican, as staged in his work "Choosing my Parents." In an interview, Mullican related how he had already posed these questions at the tender age of eight and concocted a story to go with them, which is illustrated in the book by a drawing of the beginning of the story. Mullican's story goes as follows:

I believed that I had been lying on a conveyer belt with the other pre-babies, or angels or spirits, whatever you want to call them, and that there were these little doors with names above them. I believed that when I passed by the door that said Mullican, I chose to enter that shoot [chute] and that becagime $[$ sic $]$ my life. $(2011$, p. 153)

The beginning of a narration-whether in words, as an image, or a film-often involves an attempt to understand and explain the origins of the happenings beyond the narration. In the interviews we carried out with network actors and bloggers in the study "Communicative Publics in Cyberspace," which can be regarded as narratives, we repeatedly came across the phenomenon whereby the causes that lay behind particular trajectories in their lives were mentioned in the first few minutes of an interview. Take a 23-year-old blogger as an example whose blog is dedicated exclusively to fashion. On his blog he writes about fashion shows, fashion trends, and individual designers. Fashion has become his purpose in life so much so that he has also configured his own life as a gesamtkunstwerk. "Life as aesthetic staging" is the core category we used to identify the blogger's life principle based on our interpretation of the interview. The 
foundations for this life principle were laid in early childhood experiences, we believe, which were mentioned right at the beginning of the interview. Two experiences in particular had a formative influence on him: an encounter with a medium and an encounter with a person. He recalled, "when I was nine, I held a copy of Vogue in my hands for the first time and I sort of had the feeling 'yes, this is it, this is what I want to do one day'." A few minutes later, he described the second encounter, with a person who turned out to be very important for his outlook on life: "My granny had a great influence on me because she always came across as a kind of grande dame, from the way she wore her make-up and used perfume to the way she wore her clothes." The 23-year-old used the interview to tell a story in which he located his chosen life plan on a timeline. The narrative began with what he considered to be the start of his life plan and the story, or rather the interview, ended with his characterizing himself as an expert on fashion issues who is capable of making objective judgements, from which we deduced that he was distancing himself from bloggers who "only blog on their opinion." He continued to pursue the path which he set off on in his childhood: New episodes were added to the beginning of his narration and in his imagination-the interview seems to suggestthere would be a perfect ending in the future, for example when he managed to work as a fashion journalist. The story of conceptual artist Matt Mullican also has an ending, namely one that was still in the future when he was telling it:

I believed when I was a child ... that Fate controlled my life. I believed that Fate had a television set on which he saw me and that he had a big lever, which he pulled down. The lever would have my birth date on it ... and my death date, 2014.... However, the date changed later on. 2014 is the earliest I have ever set my death and it is becoming a bit scary because it is so close. But I have also set the year of my death at 2036, 2038 or even 2040. (2011, p. 153)

The end of a narrative does not only give the narrative a goal but also the narrator's life, and the beginning — when seen retrospectively from the end-gains a new meaning.

Between the beginning and a potential end stretches a sequence of events or a chain of reasoning which is grouped around the middle. The middle, Norbert Meuter explains, is a "particularly meaningful sequence of actions and happenings to which looser events can be attached" (1995, 
p. 135). In the case of the 23-year-old blogger on fashion, what we called "life as aesthetic staging" could be regarded as the middle of the narrative. In the case of the artist Matt Mullican, the breaking down of the world into parts and the subsequent artistic rearrangement of those parts could be regarded as the middle of the narrative. Here the narrative becomes apparent in its drawn objects. Although the two narratives are completely different in character-the blog here, works of art there-what they have in common is that many works of art, blog posts, and statements made by the artist or the blogger in interviews relate to the middle of their stories.

With a beginning, a middle, and an end, a narrative is provided with structure. What is narrated becomes comprehensible to the person telling the story and Others listening to it as well. It is irritating when the temporal structure of the narrative fails (Kraus, 2000, p. 7). The narrator then appears to be somebody who cannot make sense of their life or does not know what they want (Kraus, 2000, p. 9; 2007, p. 39). If telling stories is one method of structuring one's own life and the world, in contemporary society, in which traditions are under threat on the one hand and the world is becoming increasingly complex and confusing on the other, this method faces a special challenge. In these circumstances, it would be fair to assume that the need to tell stories is very pronounced because doing so promises an increase in the type of security which guarantees a wellstructured life and which is absolutely essential as a counterweight for the unavoidable and also important insecurities which exist.

\subsubsection{Time as a Product of Storytelling}

Time is not only a point of reference for telling stories; it is also a product of storytelling. The past, in the form of experiences, only takes shape through telling and retelling stories (Waldenfels, 2001, p. 20). Not only do past events become visible through telling stories; they are also subject to a process of configuration because narrative accentuates, relativizes, omits, and adds things. Wolfgang Kraus calls storytelling the "essence of the social construction of reality" $(2000$, p. 4$)$. This is as true for past reality as it is for future reality. In line with Michael Neumann, narrative can also be characterized as a stage for the imagination on which possible actions can be envisaged (2000, p. 286). And not only that: The narrative stage makes it possible to rehearse things mentally $(2000$, p. 286). "What if" questions are popular communication games in all sorts of online networks. Questions like "What if you could rule the country for a day, what if you had to do sport, what if you only found clothes for the opposite sex 
in your wardrobe, what if you weren't allowed to drive a car for a year starting tomorrow?" " "Was wäre wenn?" [What if you?] discussions in the group "Nicht P.E.R.F.E.K.T. aber E.I.N.Z.I.G.A.R.T.I.G," 9th April 19 to 7th May, 2010; Studiverzeichnis, n.d.) guide network actors towards various potential future scenarios, encouraging them to reconstruct themselves for such a future. As Kraus says, every narrative inherently includes a notion of the future because it moves towards something which does not exist yet $(2000$, p. 5$)$. Mental rehearsals through narrative point to a possible future but not to one which is inevitable.

Expectations for the future which are formulated in narrative do not pluck ideas out of thin air; they take them from the past. Illuminated by the narrative beam of reflection, the past provides evaluations, priorities, patterns of behaviour, and rationales which serve as templates and blueprints (Meuter, 1995, p. 143). This is a kind of knowledge which has its roots in a narrative examination of the past and which points to the future, a kind of knowledge which expresses a "relationship to being," as Karl Mannheim, sociologist of science, puts it. What it stands for and why it is sought after cannot be "another kind of knowledge but only a kind of becoming in any case-a kind of becoming something different" (1964, p. 204). Thus Mannheim posits that knowledge also serves as a cominginto-being, namely

- A coming-into-being of an individual

- A coming-into-being of the world

- A practical domination and restructuring of the world for our human goals $(1964$, p. 205$)$

Mannheim is critical of the fact that modern society only really appreciates and preserves one kind of knowledge, namely knowledge for the sake of control combined with practical knowledge, which aims at changing the world in practical terms (1964, p. 207). Questions which cannot be answered through observation, measurement, and mathematical deductions are excluded from this culture of knowledge (1964, p. 208). More recently, philosopher Paul Liessmann voiced similar criticisms when he spoke of an industrialization of knowledge which is solely beholden to application-oriented and utilitarian principles (2006, pp. 38ff.). This type of knowledge keeps its distance from forms of knowledge which relate to the question "what it was that calls this or that into being" (Mannheim, 1964, p. 208) or which, as Liessmann wrote, represent a kind of 
penetration of the world and which are directed at recognizing, understanding, and realizing (2006, p. 29).

Depending on what type of knowledge they convey, narratives engender different pasts and different futures. When application-oriented and utilitarian forms of knowledge dominate, solidity dominates too, for this type of knowledge is dependent on solidification, as represented by analytic logic, unambiguousness, definitions, formulas, measured quantities (Assmann, 1991, pp. 183ff.). We encounter fluidity, in contrast, in narratives which are characterized by 'why' questions, by attempts to understand, by assumptions, reflections, empathy, and fragments of thought. Solidity tends to be found in written narrative texts, fluidity rather in oral narratives and, increasingly, in non-verbal carriers of meaning, for example in a collection of images. Whereas a verbal language consists of discrete units of meaning which do the groundwork for analytic logic as well as the need for abstraction and calculation, the image, as a presentational symbol, includes a wide range of possible interpretations, accompanied by a certain degree of vagueness. This vagueness has an aversion to the solidification of impressions and messages.

In the field of morality and ethics, Martha Nussbaum prefers vague statements. She writes of the "thick vague conception of the good" (1990, p. 217) which draws on Aristotle, justifying the advantage of vagueness in that it allows for many different specifications in concrete cases and is therefore closer to the richness of human life (1990, p. 217). Without that thick, vague conception, we are often given precise answers which are, however, wrong (1990, p. 217). Nussbaum, admittedly, does not refer specifically to narrative, but a theory is also a type of narrative which is equally in need of vagueness; like Nussbaum's theory, narrative is, after all, an integral part of everyday culture. Everyday narratives have to supply systems of meaning which allow enough leeway to provide orientation to people of different ages and with different roots. Vague narratives are best suited for that because vagueness tolerates variation, liquefaction, and open horizons.

Aleida Assmann, who discusses the relationship between solid and liquid as a figure of thought, holds that cultural activity requires three elements: solidification, liquefaction, and oscillation between the two poles (1991, p. 182). When applied to the discussion at hand, this means that we need narrative as an unquestioned, solid foundation for our being on which we install ourselves and act as though everything were fixed and will remain so for ever. That is how we gain trust in the world in which we live. 
But there are situations in which we are dependent on the opposite: on the unfinished, the fluid. According to Schutz and Luckmann, such a situation arises when

- "[A] problem is set off against a background of self-evidency" (1974, p. 10).

- The "current experience" can no longer be integrated in a "typical reference schema" (1974, p. 10) for our narrations.

- An "actual experience may contradict a type" (1974, p. 10).

Such situations undermine our confidence because they deprive us of our basis for acting (Zoll, 1993, p. 3). We are more likely to overcome them when our narratives have room for interpretation and manoeuvre, when they include ideas which can be developed further, in short, when they are unfinished. In structural terms, such situations apply to the caesuras in our life trajectories, for example during the transition from childhood to adulthood, or from the workforce to retirement.

Such situations also arise on a social level, even more so nowadays, caused by increasing mobility, whether real or virtual, which brings us into contact with other systems of symbols which put our own into perspective or make us question familiar value systems and norms as a consequence of political and economic crises. Day in, day out, we are confronted with events which we are no longer able to integrate automatically into the interpretative systems we are familiar with. The subject is facing new challenges, requiring changes in thinking, new perspectives, a search for new explanations. The old tales have started to crumble. Which stories do people tell these days? What tales do they hope will help them get back on their feet?

\subsubsection{Space}

Just like time, space creates a context for narrating. And in this case, too, the notion of context relates, firstly, to the setting or framework of the narrative and, secondly, to its structural relationship. The second dimension implies the constitution of space in the narrative itself whereby space appears as the product of narrating.

Whereas the connections between narrative and time focus on the narrative flow, the progression of a narrative, procedural matters, the before and after, in the connections between narrative and space, it is the 
descriptions of the position of narrative elements and their relationship to one another as well as questions of proximity and distance, of expansion and affiliation, of openings and limitations which gain in importance.

Long before the introduction of digital media, space and narrative were linked in the concept of narrative space. Exploring the history of gossip, Birgit Althans (2000) reveals close connections between gossip, as one commonplace narrative form, and space, as the housing, or encasement, and product of narrating. She developed her theory using the example of the history of doing the laundry, which was traditionally a communal activity and was always accompanied by stories which the washerwomen swapped amongst themselves. Part of the process was carried out in the house and part of it outside. The stories varied depending on where they were told. The repeated phases of soaking the washing with endless amounts of water inside the house were associated with the narrating of old stories, legends, and horror stories (Althans, 2000, p. 57). The beating and rinsing of the laundry outside the house was a loud and cheerful affair, Althans established, during which stains on underwear which bore witness to the owner's sexual activities were subjected to professional interpretations (2000, p. 49). While chatting and gossiping, the women's own practical knowledge on how to remove the stains was interwoven with speculation as to their origins $(2000$, p. 49$)$. Through the combination of manual labour and narrative, the washerwomen constituted a working space which was located in the sphere of reproductive work.

In the same way that women had their washing places, men in the seventeenth and eighteenth centuries had their coffee houses, although it has to be said that coffee house gossip did not just accompany work, as was the case with the washerwomen, but was the primary reason for getting together $(2000$, p. 80$)$. Men swapping the latest information about financial matters, business, and politics served to help cover their costs of living $(2000$, p. 80$)$. In contrast to the washing place, where speaking constituted the working space in conjunction with the practical work, in coffee houses, speaking alone was the space-constituting medium. Coffee house gossip is redolent of gainful employment outside the home. It arose at a time when employment outside the home was beginning to liberate itself from its connection to reproductive work and be defined as a working space with masculine connotations.

At one and the same time, the coffee house was the housing for and product of the talking and chatting. It functioned as a housing by channelling the narratives in space thanks to its opening hours, its arrangement of 
tables and chairs, the types of meals provided, and having other guests nearby. Having said that, it is clear that coffee houses were open to narrative practices of all kinds; when they became a place of work, this was the result of specific, work-related narrative practices. It is quite likely, even, that coffee houses only dedicated space to work in specific corners while other corners were reserved for enjoyable chats, with absolutely no designs on work at all. Within the large space in a coffee house, different narrative spaces arose.

Examples for the link between space and narrative are not only to be found in historical contexts, however, but in modern life-worlds as well, as illustrated by Stephanie Porschen and Fritz Böhle in their (2005) study on storytelling in technical, industrialized work processes. Storytelling often begins when the technicians have breakfast together and swap their experiences with the machines (Porschen \& Böhle, 2005, p. 56); it often continues in situ, that is, when standing in front of a machine, and during work breaks. The contents of the stories include disruptions in production sequences, faulty machines, and difficulties when dealing with computers. The narratives serve to troubleshoot, find solutions, and pass on experiences. Porschen and Böhle recommend that companies maintain, or even create, free space for narrating and listening and that they do not belittle it as tittle-tattle $(2005$, p. 63$)$ as it is vital for optimizing production processes.

Whereas the work-related coffee house gossip transforms recreational space into working space, partially or totally, the technicians' storytelling extends official working spaces into social space. The actual working space with its machines is complemented by an immaterial narrative space which constitutes itself during the breaks and, from Porschen and Böhle's perspective, represents an essential addition to the material working space (2005, p. 63).

Just how much narrating is intertwined with the generation of different kinds of space is illustrated by the following example from a religious context, that of the confessional box (Hutton, 1988, p. 133). The confessional embodies the narrative of guilt, remorse, and atonement, shaping what is talked about during the confession. The penitent is required to undertake rueful soul-searching whereas the confessor is obliged to forgive. The narrative which materializes in the confessional is not only encoded in the what and how of the penitents' self-examination but also in their bodies as its architecture forces them to kneel in humble spirit. From this perspective, the confessional box is a powerful housing indeed. 
At the same time, it is the form and content of the narratives demanded of the confessional which make a confessional what it is. The confessional box would not be a confessional if sinners and priests did not meet there and take on their predefined roles, or if it stood somewhere in open country and was not being used. It relies on specific narrative practices to confirm that it is a confessional box. The confessional is a space created by narratives which initiates and shapes new narratives; as a result of this, it is repeatedly recreated anew.

The examples of narrative spaces from different historical periods and different spheres of life serve to approach the next topic, namely spaces as the product of and housing for narratives, on a more concrete basis, which will then be anchored in a theoretical framework.

\subsubsection{Spaces as Products of Narrating}

Rudolf Maresch and Niels Werber have addressed the question as to what can be identified as space in the first place. What qualities stand out as pertaining to spaces $(2002$, p. 13$)$ ? Do spaces necessarily have a material substrate or are they constituted with the help of cultural codes (2002, p. 13)? Do they simply exist or do they have to be created $(2002$, p. 13)? Maresch and Werber answer their questions by referring to the existence of hard (material) and soft (immaterial) spaces, conceptions of space, and spatial concepts which exist alongside each other, which often complement each other, and which can also displace each other; on top of that they also refer to hybrid spaces, which consist of "physical and cultural mixtures" (2002, p. 13).

The spaces outlined in the introduction to Sect. 2.1.2 cover each of these types of space. The technicians telling each other stories at breakfast create an immaterial working space; the coffee house and the confessional box represent material spaces but have emerged from the immaterial in the form of narratives and as such are endowed with a hybrid character. The washing places mentioned earlier also represent hybrid notions of space; material, spatial reality in the form of containers, tools, and possibly a roof, intermingles with the manual practices and speech acts of the washerwomen to create a complex spatial entity in which material and immaterial elements affect each other and are dependent on each other. Narratives are associated with all of the types of spaces defined by Maresch and Werber. Immaterial narrative spaces can become material and, as such, can give rise to new narratives, which can, in turn, become material, and so on and so forth. 
Although I have taken immaterial spaces for granted in the discussion so far, a more precise justification is necessary as this conception of space collides with conventional conceptions which exclusively represent realities which are perceptible and tangible to the senses. My justification harks back to Georg Simmel, who developed an alternative to the conventional, common, everyday notion of space. For Simmel, a kingdom does not come into existence based on a certain number of square miles but thanks to the "psychological powers that hold the inhabitants of such a realm together politically from a governing center" (1922/2009, p. 544). For him, spaces are realized by "an activity of the psyche," which is, however, integrated with the activities of others $(1922 / 2009$, p. 544$)$. It follows on from this that Simmel is concerned with social interaction between individuals, in the course of which that space is considered to be "filled and enlivened" (1922/2009, p. 545).

Simmel does not claim that space has no material quality, but he does say that sociocultural aspects precede materialization and are the decisive criteria, which is underlined by his comments on neighbourliness: "It is not the form of spatial proximity or distance that creates the special phenomena of neighbourliness or foreignness. ... Rather, these too are facts caused purely by psychological contents" (1903/1997, pp. 137-138). It is not discernible whether Simmel assumed that the spiral of creating space proceeds in the same manner, namely that the spatial conditions which arose out of the activities of the psyche, in turn, initiate and influence new activities of the psyche.

A further aspect of Simmel's notion of space is well worth mentioning in view of the subject matter of this book, Storytelling in the Age of the Internet. According to Simmel, "there is only one single universal space, of which all individual spaces are portions, so each portion of space has a kind of uniqueness" (1922/2009, p. 545). For Simmel this universal space is possibly the universe itself, within which individual spaces are created as portions. This pattern can be applied to the various hierarchical levels of being. It was already demonstrated with the example of the coffee house, which can be segmented into spaces for working or for pleasure, depending on the focus of the narratives of the guests sitting there.

The internet can also be regarded as a universal space which can be subdivided into many individual spaces in the form of chats, blogs, wikis, and discussion forums, amongst others. It can be assumed that Simmel ascribed a certain degree of homogeneity to the individual spaces when he described their coming-into-being as "the human way of binding 
unbounded sensory affections into integrated outlooks" (1922/2009, p. 544). Given our contemporary pluralist society, which Simmel could not have had in mind in the 1920s, the assumption of homogeneity has become questionable, on the one hand, because it does not account for the coexistence and community of people from different cultural groups and, on the other hand, because it can be used to justify exclusion mechanisms affecting anybody who deviates from the norm. However, a social construct that should be perceived of as space requires a certain degree of coherence in order to be able to appear as space in the first place.

Simmel does not talk about narratives but about the "activity of the psyche" (1922/2009, p. 544); however, narratives can also be subsumed under this notion as they create that shared meaning-context by which a space stands out from its setting but is not severed from it.

In the examples mentioned earlier on doing the laundry, politics, and technology as well as guilt and atonement, narrative practices are made use of to construct a "common referential space" (Taylor, 1986/1991, p. 27), which stands apart from its surroundings but also has crossovers. This is catered for by the narrative practices which transport values, orientations, and principles between different spaces.

The question is how autonomous these practices are, or how autonomous we are when constructing narrative spaces. The practices may be rooted in individual biographies, but they cannot be seen independently of the society in which they arose. The erotically tinged gossip of the washerwomen cannot be seen independently of a society in which sexuality is inherently raunchy; the exchange of information in the coffee house takes on its significance against the background of the economic and political nature of being better informed in the emerging capitalist society; the confession is of value in conjunction with the Catholic promise of salvation.

Using the example of the autobiographical narrative of a Japanese man, Shingo Shimada describes how the cultural elements of Japanese society are processed by the narrator "into a coherent, individual life story" (Shimada 2006, p. 78). The male protagonist, who is professionally very successful, portrays his curriculum vitae as one path which is integrated into an interpersonal and institutional network; his decisions are made within this web depending on other people, without the narrator understanding this as being dependent $(2006$, p. 90$)$. By defining sovereignty as the skill of "independently and judiciously dealing with the opinions of others and being able to determine his life's journey in harmony with his 
social environment" (2006, p. 85), his story gains autonomous and heteronomous traits at one and the same time.

An activity, of which narrating is but one example, is, in Alexei Leontev's words, "a system that has structure, its own internal transitions and transformations, its own development" (1978/2009, p. 36) which is "included in the system of relationships of society" $(1978 / 2009$, p. 37$)$ and this in two different ways. On the one hand, narrative practices develop when engaging with cultural requirements and, on the other, they are usually embedded in social situations and are, consequently, involved in a process of negotiating meaning. Leontev's approach is similar to Pierre Bourdieu's notion of habitus (1980/1990, pp. 52ff.), in which sociocultural practices are constructed and ordered relatively independently of or dependent on their social foundation. Bourdieu appears, however, to allow more latitude to sociocultural practices than Leontev does. The Leontevian formulation that activities are "included in the system of relationships of society" $(1978 / 2009$, p. 37$)$ implies a strong, social restriction to narrative practices. Notwithstanding the extent of sociocultural conditioning, narrating generates symbolically charged spaces, which become the housing for further narratives.

\subsubsection{Spaces as a Housing for Narrating}

As soon as spaces are created by narratives, the relation between narrative and space is reversed. Space becomes the housing, or rather the condition, for narrating, which influences the form and contents of narrative practices. The generating power of space has an effect on this as the carrier of a specific type of symbolism which narrators draw on, voluntarily or not, when developing their narrative practices (Dickhardt \& Hauser-Schäublin, 2003 , p. 33). The symbolic vehicle of the confessional box allows little leeway for the verbal and physical narrative practices of those who enter it. It prescribes a certain posture and, in connection with the official list of sins, or the ten commandments, the how and the what of the confession.

Michel Foucault, too, addresses the restrictive cultural code of spaces, taking total institutions like prisons, schools, barracks, hospitals, and monasteries as his examples. The story that these institutions tell is of "coercive observation" (1975/1979, p. 170), which forces the residents, inmates, or clients of these institutions to behave in conformity with what the disciplinary power considers to be normal. In conjunction with architectural features like long, straight corridors where everybody would inevitably meet up when they left the monastic or prison cell, the sickbay, or prison 
yards and playgrounds which could be observed from every direction, or inspection requirements, surveillance rituals, and sanctions, Foucault's coercive observation operates with optimum effectiveness (1975/1979, pp. 14lff.). Narratives which go beyond the prescribed norms have very little chance in total institutions. Foucault takes a hybrid notion of space as a basis for his analysis by mapping out the coordination of material and immaterial systems of symbols for a surveillance apparatus which provides for a deterministically influenced relationship between space and the narratives which are potentially found within it.

Another example for the defining power of space in more recent times is the university as an institution, which is in the process of redefining itself as a space for quality management under the mantle of modern educational concepts. Universities are reconstituting themselves in accordance with a set of evaluation tools, which says something about belief in the quality of education. Quality is considered to be a variable which can be measured using these tools, arranging quality in a hierarchy, squeezing it into a yes/no format, and subjecting the educational processes to standardized criteria regardless of the contents and character of the learning events. As evaluation systems can also be used to monitor and appraise teaching staff, and thus to advance or hinder their academic careers, it can be reasonably assumed that the beliefs about education that the evaluation tools embody will become hallmarks for university courses. That would come very close to the technologies of standardization and discipline as described by Foucault.

Even though the spaces which are constituted by narratives always have an influence on the narrative practices which arise in them, this influence does not necessarily have to be restrictive. It can also develop towards the expansive, the diverse, the experimental, as discernible in the interview with conceptual artist Matt Mullican, who said: "In fact, I love cities that are so iconic they almost become a graphic sign" (2011, p. 195). Commenting on the walled city that he had drawn, he wrote: "The city is a box that enables me to put everything there is inside of it" (2011, p. 203). This "everything" is neither restricted nor limited, and yet the box remains a housing.

Let us now turn to the virtual narrative space of the internet. How do the specifics of this space colour the narratives of its users? A core feature of virtual space is that its users do not have a physical presence, at least not in the sense of having real encounters. I would like to illustrate what this means for narratives in the internet by using some exemplary statements 
from the interview with a 12 -year-old girl who regularly used a digital children's network, SWR Kindernetz (2020). The 12-year-old participated in online role-playing games together with Others; at the same time she was a member of her school's theatre group. When comparing the online and offline role-playing games, one observes that corporeality is a key factor which plays a role at school and is absent online. Her explanation went as follows: “In SWR Kindernetz you don't see the other people who play a role, well actually, you don't see anything about them ... and in the theatre group you have to express your role with facial expressions and gestures." She found that acting at school was much nicer but then pointed out that the digital role-playing games allowed her to carry out experiments: "Usually I play the bimbo, although that's not what I'm like for real, but I find it really exciting to play that role." Shortly afterwards, she revealed that she also experimented with gender roles online, sometimes playing a boy and sometimes a girl. From the point of view of the young network actor, the narrative housing of the internet has an effect on the genesis of her stories due to the inadmissibility of corporeality, being both restrictive and plot-enhancing at the same time. Her response to this contradiction was equally ambivalent.

\subsubsection{Spatial Connections}

Nowadays we move in many different narrative spaces rather than in just one. Under the conditions of a pluralist society, narrative spaces are multiplying. Wolfgang Welsch talks about a "life in the plural" (1991, p. 352), which unfolds at the crossing points of different social and cultural settings. These crossing points occur daily and often in quick succession. Whereas the stories told by family members at the breakfast table are about family matters, the discussions at a meeting later on that morning, in an architectural practice, for example, concern plans for a residential development around which various stories have grown up about why what should be built and how. At lunch, a get-together with a friend is on the programme, including the saga of their ongoing divorce; the afternoon's workshop includes a debate about the (hi)story of architecture. After work, your children recount what happened at school, your spouse talks about what went on in his or her job as a doctor, lawyer, or software developer, and after the evening meal you start planning your next holiday online, hungering for the big wide world and taking part in stories about adventures, foreign traditions, and cultures. 
This description presumably covers just a few of the narrative spaces which the modern subject can be confronted with on a daily basis. Some of them are located close by, in geographical terms, whereas others are far away, in other countries and on other continents. Digital media help transport them into our field of perception and experience. In the wake of global migration flows, narratives from other cultures literally arrive on our doorstep as well. Dickhardt and Hauser-Schäublin refer to multiethnic cities like London, where migration has caused one place to constitute itself as an ensemble of highly diverse places; in other words, places from all over the world have gathered together in one place $(2003, \mathrm{p} .15)$. What I have just depicted here as a development from the twenty-first century reminds us of Simmel's proposition whereby, within a large space, many small spaces are portions of the large space (1922/2009, p. 545). These "portions of space" reflect the different, culturally configured ensembles of individual life stories.

The juxtaposition of various narrative spaces is not the end of the story, however. According to Daniela Ahrens, spaces are not immobile (2003, p. 187). It is their sociocultural constitution which makes them mobile, with their narratives bridging the gap between these spaces. When people from different narrative spaces communicate with each other, these narratives - regardless of whether the communication is taking place virtually or face to face-come into contact with each other. Of course, it is conceivable that the narratives told by the Other are ignored, misunderstood, vilified, or even fought over (Welsch, 2001, p. 261). On the other hand, in the interests of global political and ecological challenges and the global economy, it is not desirable for the different narrative and cultural spaces to remain clearly distinct; instead they should become closely connected points of reference (Dickhardt \& Hauser-Schäublin, 2003, p. 15). Wolfgang Welsch has predicted that life forms will no longer end at the borders of single cultures but will cross them and permeate each other, a development which he has termed transculturality (2001, pp. 275ff.). Transculturality does not happen automatically, however. It requires existing narratives to be scrutinized, transformed, and discarded on a large scale and new narratives to emerge.

The virtual narrative spaces which are at issue in this book and which count as the most recent narrative spaces worldwide pave the way for transnational narratives as almost no other narrative space has done so before, pushing forward possibilities for relativizing, transforming, and restructuring narratives by connecting interpretations and symbols from 
various cultural contexts and turning them into novel transcultural systems of meaning. The questions still to be answered in the course of this book are:

1. What kind of spaces are constituted by narratives in the internet?

2. Conversely, what effect do the familiar structures of virtual spaces have on the narrative practices and contents?

3. How is the Foreign dealt with in the narratives of Others?

4. To what extent do transcultural elements crop up in digitally assisted narratives?

\subsection{The Functions of Narrating}

A 26-year-old Yemeni blogger declared in her interview "I'm passionate about writing," revealing that at the age of 15 , she had already started to keep a diary. The blogger of today compares herself to the diary writer at the time: "There is no difference between the online and offline [name of the blogger]." She uses her blog to write about her everyday life and political events. It is not clear from the interview whether she already wrote about politics when she was 15 years old. What has stayed the same over the intervening years is that she writes about everything that is on her mind. She makes use of writing to configure her life and her relationship to the world as a narration (Kraus, 2000, p. 4). Narrative writing implies a mental move in two directions, both towards herself and towards the Other. The two directions are related, of course, but I will analyse them in two separate subsections in order to be able to describe them.

\subsubsection{Narrating as a Technology of Self-construction}

Narrative writing is characterized by Michel Foucault as a "technology of the self" (1988, p. 27), in which writers acquire knowledge about themselves so as to understand themselves better. Foucault contextualizes this technology in the culture of "taking care of oneself," which he describes as originating in the Greco-Roman philosophy of the first two centuries of the early Roman Empire (1988, p. 19). Technologies of the self are characterized by being concerned with oneself, paying attention to oneself, taking care of oneself. This can take on the form of "taking notes on oneself to be reread, writing treatises and letters to friends" (1988, p. 27). As an example of a technology of the self, Foucault quotes part of a letter 
from Marcus Aurelius, before he became Roman Emperor, to his teacher, friend, and lover, Marcus Cornelius Fronto, dating from 144 or 145 A.D., which may not remind us of modern-day status messages in digital networks in its choice of words but certainly does so in its import:

Hail, my sweetest of masters. We are well. I slept somewhat late owing to my slight cold, which seems now to have subsided. So from five a.m. till nine I spent the time partly in reading some of Cato's Agriculture, partly in writing. ... Then we went to luncheon. What do you think I ate? A wee bit of bread, though I saw others devouring beans, onions, and herrings full of roe. $(1988$, p. 28$)$

The young Marcus Aurelius, 24 or thereabouts, describes in minute detail in his letter what he had thought, done, and felt, who he met, and what was talked about. In style it is not dissimilar to the reports written by a 14-year-old blogger from a German-speaking country in 2011. On his blog, he wrote:

I was on holiday over the weekend. After driving for hours and hours and after lots and lots and lots of mountains, we finally landed up in the Eifel region in Rhineland-Palatinate. When we arrived on Friday evening, first of all we had to clean up the house that we had rented.

Five days later the 14-year-old blogged: "At short notice, I decided to do without animal products like milk and eggs, for example, from now on. ... Today I tried to eat only vegan stuff for the first time."

Both communications include numerous elements of care, such as taking care of one's health, or one's physical and mental well-being. The authors of these communications speak about themselves, constituting themselves as individuals in the process who are embedded in social relationships (the blogger describes the excursion as an undertaking with Others, the salutation in Marcus Aurelius' letter also marks a relationship), who are taking proper care of their health, who are mobile, who are pursuing intellectual interests. Paul Ricour summarizes the connection between narrative and self-construction in his proposition that "in the reflexive form of talking about oneself narratively [se raconter] this personal identity is projected as a narrative identity" (2005, p. 99).

The individual's own personality lies at the heart of talking about oneself narratively; at the same time this is no solitary activity as it plays with the existence of the Other, with that special Other who should read what 
the individual wants to communicate. Marcus Aurelius expects his friend to do that; the blogger expects his so-called followers to read and comment on his posts. The blogger calls them "visitors" in his interview and it is important to him that they are "real visitors" and not machines; here he is expressing his interest in being understood, albeit implicitly. The Other does not come into play by chance; the significance of the Other as an essential component of Self-construction will be explored in more depth in Sect. 2.2.2. In this section, self-referential narrating is in the foreground. Foucault points out that the technologies of the self, which stand in the tradition of a culture of taking care of oneself, are not exempt from criticism, interfering as they do with the principle of "Know yourself," which has its origins in the tradition of Christian morality according to Foucault (1988, p. 22). From the perspective of Christian morality, Foucault believes that taking care of oneself has something immoral about it as it provides "a means of escape from all possible rules" (1988, p. 22). Foucault observes that the members of contemporary society have inherited "the tradition of Christian morality which makes self-renunciation the condition for salvation. To know oneself was paradoxically the way to selfrenunciation" (1988, p. 22).

Despite the suppression of taking care of oneself by Christian morality, we still come across this care in Christian cultural circles. It appears as though care, in the guise of talking about oneself narratively, has been given a new boost, not least because of media stages like talk shows and the internet. Digital networks represent global narrative spaces on account of their users. The worldwide visibility of a passion for telling stories on media stages signals the unavoidable nature of the Self; it reveals the significance of storytelling for constituting the Self, to return to Wittgenstein, which we cannot refrain from doing any more so than walking, eating, or drinking $(1953$, p. 12e). This proposition will be discussed later to the extent that those aspects of talking about oneself narratively will be covered on which the constitution of the Self depends. As illustrated by the examples cited at the beginning of this section (the letter from Marcus Aurelius and the 14-year-old's blog entry), because the narrative technologies not only relate to the Self but also construct the Self, I would like to modify Foucault's terminology and talk of technologies of Selfconstruction. This certainly appears to me to be in the spirit of Foucault in as much as his technologies of the self "permit individuals to effect ... a certain number of operations on [themselves] ... so as to transform themselves" (1988, p. 18). 


\subsubsection{Orientation and Agency}

The purpose of narratives is not to reproduce reality, according to Wolfgang Kraus, but to search for meaning $(2007$, p. 36). In the process of narrating, things are selected, structured, accentuated, or left out, with the goal of gaining a new perspective on what has been experienced $(2007$, p. 40) or fulfilling the need for orientation (Neumann, 2000, p. 292). We have to imagine the world as consisting of bigger and smaller stories so that we can find our way about in it $(2000$, p. 292). Narrative performs the function of extracting "a finite whole from the infinite entanglements of reality" (2000, p. 292). In this manner, situations and actions which have been experienced become readily comprehensible and, consequently, communicable. Examples of such extracted stories include the blogger's report on his excursion to the Eifel region or the shared meal as described by Marcus Aurelius in the quotation chosen by Foucault.

Talking about oneself narratively implies an act of remembering with the help of which the flow of narrating is breached and halted. Borrowing from Alfred Schutz, Aleida Assmann conceptualizes remembering as "allowing something to become fixed" (1991, p. 185), which is connected with the creation of consciousness. Remembering implies that experiences are interpreted; it makes it possible to integrate them in a meaningcontext, making our experiences available to us in our conscious mind (Schutz, 1932/1967, p. 105). By telling stories, we make sense of the past; we learn to understand it, "for all understanding is directed toward that which has meaning" (1932/1967, p. 108). Understanding makes us capable of acting. The potential of narrating as a strategy for remembering and raising awareness has also been exploited by psychoanalysis. Recalling and narrating conflict-laden experiences from the past, and particularly from early childhood, is considered to be the first step to becoming aware of these experiences in order to position ourselves in relation to them as a prerequisite for "enhancing our capacity to assert power over our own behavior" (Hutton, 1988, p. 132).

There is an essential connection between narrative recall and orientation as an aspect of consciousness on the one hand and agency on the other. The clearer the reflexive reference to the past happens to be, the more obvious the connections prove to be; the more secure an individual is in their view of the past, the more they learn what is of relevance for their actions in the present and the future. 
A 24-year-old blogger describes this memory effect when looking back at the blog which she had been writing for five years as follows:

I find that memories are simply important for my life because you learn from your mistakes, you can remind yourself of the positive things whenever you want, and you can remember the exciting things you did and the things that you somehow messed up, or didn't. ... I just find it funny when you take a quick look at what you wrote in older blog posts and more recent ones and then you really can see how much you've changed.

It is in the process of narrating offline, in an interview situation, about narrating online that the past acquires meaning for this blogger. Through the reflexive narrating, she develops a yardstick for evaluation which helps her to differentiate between positive and negative experiences from the past. When she talks about learning from her experiences, implicitly she is referring to the consequences of actions on narrative recall. This gives her the opportunity to perform a mental dry run, including anticipating the possible reactions of Others to this action, as narrating is always aimed at Others. Searching for meaning in the process of narrating and remembering leads to options for acting in the here and now; in addition, it encourages the development of future perspectives as it also generates ideas for constituting future behaviour (Kraus, 2007, p. 34).

\subsubsection{Self-knowledge and Self-understanding}

The comment by the 24-year-old blogger already touched on the point that digital narrating is a document of the personality being moulded, this becoming clear to the blogger when she recalled her narrating in an earlier phase of her life. Michel Foucault puts knowing oneself at the heart of his technologies of the self, as we encounter in Ancient Greek and Roman texts, namely in connection with the principle of taking care of oneself $(2001 / 2005$, p. 82$)$. The self becomes accessible according to Foucault by "be[ing] concerned with oneself" (1988, p. 19). The "Know yourself' has obscured 'Take care of yourself'" (1988, p. 22). The tradition of Christian morality also places a high priority on self-knowledge, although it should be attained in reverse, namely through selflessness. Christian selfknowledge is characterized by a shift away from the demands of the self; the Graeco-Roman "know yourself," in contrast, demands an orientation towards this self. The Graeco-Roman view on self-knowledge implies empathy in relation to the self, which points to the emotional dimension 
of self-knowledge and opens up the path to self-understanding, which includes a component of acceptance beyond rational self-knowledge. As a cognitive-emotional-social technology of Self-construction, narrating opens up a multitude of paths to the Self. Recalled experiences provide the opportunity to relive events, to awaken feelings, to visualize encounters and conversations with Others, and, thus, to be able to name them.

As soon as we find ourselves on the terrain of language, we can find templates and formulas which are suitable for communicating our experiences. The world of subjective experience is overarched by the general world of language (Assmann, 1991, p. 185). Language provides a system of shared symbolizations in which intersubjectivity is anchored and consciousness illuminated (1991, p. 185). In a similar manner to memories, language indicates a solidification, something that juts out of the flow of our experiences, something which turns implicit knowledge into explicit knowledge, propelling it into the sphere of our consciousness. An example of how narrating can produce awareness is illustrated in the story about her nickname, Gaia, recalled by a 21 -year-old blogger from Italy in her interview. The story of this nickname goes back to the blogger's childhood. When she was around 12 years old, she read the series of novels called Fearless. The protagonist in this series is a 17-year-old girl called Gaia, who lives in New York and tracks down criminals. One characteristic of this figure which impressed her the most as a 12-year-old was, as she recounted, that "she has no fear gene and so she doesn't feel fear." Gaia became the "great role model" for the now 21-year-old blogger. Like her role model, she started to learn martial arts and also became more courageous. She has retained that courage over the years, also making use of it in her blog. She herself points out the link between her earlier role model and her behaviour in her blog, as the following quotation shows: "It's no longer important at all what other people [who read my blog] actually think of me." The story she experienced preceded the story she told, but only by telling the story did she take possession of the narrative, recognizing and naming the connection between the media figure and her own personality, only now becoming aware of the lasting effect of an experience from childhood, discovering who she is and who she wants to be.

In the spirit of Foucault, technologies of Self-construction arise at a specific point in life, which is known as hora in Greek $(2001 / 2005$, p. 86). This is the phase in which the young man grows up. Why Foucault only referred to males in his theory is inexplicable because the task of Selfconstruction applies equally to females. This task is never concluded, 
being, as Foucault admitted, "an obligation that should last for the whole of one's life" $(2001 / 2005$, p. 87$)$, although it does come to a head in phases of biographical upheaval. In this book the digital narratives of 11 to 32-year-olds are investigated. In this phase of life, two caesuras have to be mastered, one being the transition from childhood to puberty and the other the transition from adolescence to adulthood, processes which are assumed to last for a relatively long time nowadays.

Narrating as a form of self-referentiality is not only relevant for today's adolescents and adults as a strategy for coping with biographical upheaval but also when faced with the plurality of life forms and interpretations of the world as well as the resulting convolution of options for the self (Helsper, 1997, p. 177). The dilemma of the self-referentiality of the subject in today's society is being able to find the right degree of selfreferentiality against a convoluted background. If the required amount of self-referentiality falls short, the Self becomes the plaything of external constraints; if it is ramped up too much, this leads to an inability to make decisions (1997, p. 177). This dilemma underlines the importance of narrating as a technology of Self-construction as it helps detect the right amount of self-referentiality thanks to its share of reflexivity.

\subsubsection{Coherence and Change}

As a reflexively performed technology of Self-construction, narrating does not become superfluous beyond the phase of becoming an adult. It fulfils two conditions which signal that it is a lifelong, indispensable technology. In keeping with Sylvia Pritsch, who thematized writing as a location for self-assurance and transgression alike, narrating, too, whether written, or using body language, or with the help of things, can be ascribed a dual nature $(2008$, p. 37). Narrating covers both moments of solidification, in the form of memories and linguistic naming, which promote self-assurance, and moments of liquefaction, in the form of interpretation and accentuation, which facilitate transgression. Narrating is a constitutive technology which promises narrators that they will overcome perceived boundaries (2008, p. 37). In Foucault's words, it helps individuals to bring about

by their own means ... a certain number of operations on their own bodies and souls, thoughts, conduct, and way of being, so as to transform themselves in order to attain a certain state of happiness, purity, wisdom, perfection, or immortality. (1988, p. 18) 
For Paul Ricour, the concept of narrative identity offers insights into the relation between two types of identity" :The immutable identity of the $i d e m$, the same, and the changing identity of the ipse, the self, with its historical condition" $(2005$, p. 101$)$. Its "immutable identity" arises from the genetic code, according to Ricour, and expresses itself, for example, in "physiognomy, voice, and gait, moving onto stable, or, as we say, acquired, habits, and finally to those accidental marks ... such as [a] scar" (2005, p. 102). Its changing identity, the ipse, is the product of talking about oneself narratively. Our stories about ourselves acquire different hues depending on where and when they are told, how others react to them, and how we integrate new experiences (Kraus, 2000, p. 5). They document, as Kraus puts it, "work in progress" $(2000$, p. 5$)$, or are like "a journey without end" (Hutton, 1988, p. 140) in the quest for meaning, sense, and courses of action.

Whether Ricour's allegedly immutable elements of identity really are so immutable remains to be seen; after all, both physical characteristics and habits can change. What is essential is that identities are composed of relatively solid and, at the same time, fluidly changing elements which blend in a particular way that is also subject to sociocultural transformation.

At present, the blend seems to have changed in favour of fluidity, particularly in view of descriptions of the subject in current discourse on the topic. Subjects are characterized as reflexive, flexible, mobile, and adaptable, and as such are in a position to react to the social challenges which they are confronted with at work, or in the spheres of politics, leisure time, family, or personal relationships (Bilden, 2009; Ehrenberg, 1998/2010; Kraus, 2000; Roth-Ebner, 2015; Sennett, 1998). Speed, acceleration, and change have become hallmarks of contemporary society, all of which are reflected in the (desired) constitution of the subject. The ability to change harbours opportunities for the subject because it opens up new horizons for thinking and acting, exploits unexpected resources, and bestows recognition on the subject. Change can also become a burden, however, when it is driven by compulsion rather than desire (Helsper, 1997, p. 180; Sennett, 1998). Behind the promise of individuality and autonomy as a reward for flexibility and a willingness to change lurks the risk of being overloaded and fragmented.

${ }^{2}$ I use the term identity here because Ricour uses it in his argumentation; otherwise I prefer to use terms like the Self or subject construction in order to avoid the static implications of the concept of identity. 
Given the multitude of experiences and the proliferation of tasks, subjects in the twenty-first century are faced with the task of keeping themselves in one piece and not experiencing themselves as fragmented, thus having an image of themselves as a whole. More than a few will fail at this task. According to Richard Sennett, the risk of failure is no longer reserved for the underprivileged but also affects the educated, when they no longer manage to prevent their lives from falling apart: Faced with permanent demands for flexibility and mobility in their professional lives, they lose touch with other areas of their lives, such as the family, and this is seen as a failure (1998, p. 118). Likewise, in The Weariness of the Self, Alain Ehrenberg characterizes depression as a disorder of inadequacy afflicting subjects when they can no longer integrate the multitude of changes in their lives (1998/2010, pp. 124ff.).

Paradoxical as it may sound, talking about oneself narratively does not only foster a change in personality; it also has an integrating effect because it makes it easier to find connections between experiences in different spheres of life and to allow the different parts of the personality anchored in each sphere to communicate with each other. Referring to Rivera, Helga Bilden suggests a form of integration which does not count on synthesis but is rather characterized by the fact that different and sometimes contradictory experiences, roles, emotional states, and points of view are held in one central consciousness and that strategies are developed to cope with that (Rivera, 2002, pp. 343-344; Bilden, 2009, p. 23 ). Differences are not silenced but rather examined to establish whether they can be woven into a coherent narrative of the I $(2009$, p. 23$)$.

We cannot do without this narrative representation of the Self and the coherence that it establishes, when we go by Wolfgang Kraus; doing without would lead to a dissolution of the subject $(2000$, p. 15). It is not the struggle for coherence itself that would make us ill, according to Kraus, but the refusal to struggle in the first place $(2000$, p. 15). A 24-year-old network actor from the USA recounted how she fought her battle for coherence. As an American, having the freedom to do what she wants is a matter of great importance for her. She took this desire for freedom with her from the USA to the various European countries where she lived, studied, or worked for a longer period of time. Her attempt to hold the different parts of her life together consists of taking photos of things she sees and experiences in the various places and producing a digital picture story out of them. These are not photos of famous sights but completely normal things like advertisements, a man with a funny hat, food that she 
ate: "I take pictures of my food that I eat in different countries just ... to remember 'Oh, that was a really good pizza there'." The picture stories serve to connect the different types of day-to-day life and, thus, to confirm her Self as a percipient, sentient, corporeal being. The 24 -year-old is aware of the function of her picture stories as her final comment was "It's an easier way to put things together."

Coherence and change are two conflicting poles which the subject cannot escape from. The subject constructs itself through narrative and changes itself in the process because talking about oneself narratively is about Self-construction. Talking about oneself narratively requires an I that will never solidify into a fixed shape (Meyer-Drawe, 1990, p. 122); conversely, it must never disintegrate either. As a technology of Selfconstruction, narrating must, at the same time, counter the tendencies which it, itself, produces. It has to develop an integrative effect which creates the feeling of coherence and provides protection from self-destruction. This is a never-ending process in our lives: As Assmann speculates, no connection lasts for ever, nothing that is concluded can never be reopened, and no certainty can never turn out to be uncertain again (1991, p. 183).

\subsubsection{Narrating Opening Up to the You}

Descartes was wrong. It isn't: I think, therefore I am. It's: I am because you are. (Hustvedt, 2003, p. 91)

In what has been covered so far, it has shone through on several occasions: Talking about oneself narratively does not exclude the Other. Quite the contrary: Even in contexts which are exclusively about taking care of oneself, as in the letter by Marcus Aurelius which Foucault cited, the Other is kept in mind as the one who can and should listen, sympathize, understand, and react. Narrating includes, as mentioned before, movement in two directions, towards the Self and away from the Self, but even as a movement away from the Self, narrating has an effect on the Self. This section discusses the role of the Other in the context of narrating from four perspectives: the Other as a point of reference, as a topic, as a conarrator, and as part of the narrative subject.

\subsubsection{The Other as a Reference Point for Narrating}

The movement towards the You in narrating is established in the character of narrating as a linguistic act. Language is intersubjective; "all speech calls 
for a response," according to Lacan (1953/1996, p. 206). As he explains, "speech, even when almost completely worn out, retains its value as a tessera" (1953/1996, p. 209). In a footnote to another translation of Lacan's (1953/1968) text, the translator Anthony Wilden comments on the meaning of a tessera as follows: "The tessera was employed in the early mystery religions where fitting together again the two halves of a broken piece of pottery was used as a means of recognition" (Lacan, 1953/1968, p. 101). Later it came to signify "a token of recognition or a "password" (Lacan, 1953/1968, p. 101). Thus we can assume that the words and sentences that we use resonate with the Other. Lacan posits that there is always a response "even if speech meets only with silence, provided it has an auditor" (1953/1996, p. 206).

We reckon with this response when we tell something. We make the Other-whether physically present or just imagined - the reference point for our narratives. Just how strong this need for a response is can be exemplified nowadays by narratives in virtual space where the Other is not physically present, where narrators cannot even be sure that their words are getting through to Others. Nevertheless, the Others play an unmistakably important role in the imagination of online narrators, as already indicated for the 21-year-old blogger nicknamed Gaia, who makes the Other the imagined reference point for her self-presentation. She uses her description of herself in her blog to create a particular image of herself for her followers or, as she put it,

[i]t's just that I want to show them that I'm a humorous person and like laughing about life and don't always take everything so seriously, but sometimes I do take things too seriously. I just want to give them some insights into my life.

To use Lacan's metaphor, the shards of pottery which she offers to the Others are principally her emotions and moods; the matching pieces that she desires in return are comments. She explained how she likes comments "where you can tell that they have really read it [the blog] and thought about it." She wants to be seen; she wants to be somebody that the Others will think about.

Whereas this blogger appeals to the Other as an observer and commentator on her own I, a 26-year-old blogger from the Arab world appeals to Others to be interested in his country and in a collective I. In his narratives about his country, he wants to draw the attention of the global public to 
its social and intellectual particularities which, in his opinion, are not adequately represented in the state-controlled media: "I'm trying to allow people to look into things especially in Saudi Arabia and especially when they look back to Saudi Arabia through my blog to see the social and intellectual fabric of what makes Saudi Arabia Saudi Arabia." His narratives in the internet are counter-narratives. The Arab blogger implies that his narratives "arrive," that their message is understood. He can only assume this when he has the implicit knowledge, at least, that people in different cultures think and understand in and through narratives. We acquire this knowledge by realizing that "we understand others by thinking in narratives," for example when we explain why somebody acted in one way or the other (Gergen, 1999, p. 126). We learn to see Others by making them present in our stories and offer them stories in return so that they can see and understand us.

It is this gaze of the Others that we rely on, for although we belong to the kingdom of the visible, as Käte Meyer-Drawe argues, we can only see fragments of ourselves (1990, p. 116). When we gaze on ourselves, parts of our physical form remain invisible; on the level of our mental and spiritual existence, we must reckon with blind spots as well. At the same time, these are blind spots in the autonomy of the subject, but, equally, they stand for an opening up to the Other (1990, p. 116). The gaze of the Other touches the parts of myself that I cannot see, apart from through the resonance of his/her gaze (1990, p. 117). Whether it is approving or critical, this gaze signals recognition for Jessica Benjamin, conveying a feeling that I exist, that "I am the doer who does" (1988, p. 21). Recognition, according to J. Benjamin "is the essential response, the constant companion of assertion" (1988, p. 21). With our narratives we target this gaze which comments on and reveals our actions, those matters which often remain hidden for us. And in that sense, we can say that the narrative movements that lead away from us return to us as well.

\subsubsection{The Other as a Topic and Co-narrator}

The Others are not only points of reference for narratives but also the topic of narratives and even co-narrators. They are topics to the extent that the events recounted in narratives cover not only the actions of the narrator but also those of Others (Kraus, 2000, p. 5). It is not at all surprising that the actions of Others are an integral part of narratives as the experiences and events which constitute the subject matter of narratives are always established in social exchange. Life takes place in social 
interactions and when we talk about it, social matters become an element in this narrative, for example when we describe, justify, or appraise the actions of Others. In this way we relate ourselves to each other. Michael Neumann asserts that we pay particular attention to fostering interpersonal relationships. He claims that two-thirds of everyday conversations are about interpersonal relationships, including stories about love, marriage, and the family, and an evaluation of them (2000, p. 284).

Whether the social interactions we experience already take shape as a pre-narrative or are merely a sequence of events is a question which is answered in different ways by narrative theorists (Kraus, 2007, p. 33). I proceed from the assumption that-because we think and act in narratives-we already endow the interactions we experience with the form of stories but that when we tell these stories, we revise them by rearranging, emphasizing, relativizing, adding, or missing out elements. And when we revise these experiences and events, the Other also has a role to play. How corrective interventions in the act of narrating turn out, such as whether narrators can uphold their own interpretation of events, is not a decision they can make alone. Frequently there are also co-narrators, who are present in different ways: those who are physically present, like when telling stories together, or those who are not physically present but whose concrete reactions (e.g., in the internet) take effect, or those who are not physically present and who have not yet reacted or will not react at all but who are imagined as potential co-narrators and, solely because of that, have an impact.

In joint narratives, the Other can become a co-narrator for a variety of reasons: because they were asked by the narrator, because they helped out, when the narrator forgot a name, for example, because they added information about their own role in the story, or because they corrected the narrator (Quasthoff, 1980, p. 125). Uta Quasthoff distinguishes between cooperative and antagonistic joint narratives (1980, p. 115). In cooperative narrating, the co-narrator adds orientations in order to ensure the communicative success of the joint narrative; in antagonistic narrating, the co-narrator attempts to impose their own intentions on the narrator (1980, p. 135).

As just mentioned, those who are not physically present can also become co-narrators. What Anselm Strauss illustrates in his comparison of everyday interactions with interactions on the stage can be transferred to narrating as a form of social interaction. Even when there are only two leading actors on the stage in the theatre, Strauss proposes that "there are also 
other actors who are visible only to the audience, or to one or the other of the main actors" $(1959$, p. 56). These actors can be relatives, friends, or teachers; they can still be alive or "long since dead, or arising out of the actor's past" (1959, p. 56); what they have in common is that they "expect appropriate gestures" $(1959$, p. 56) which the actors are aware of. Thus, "the interactional situation is not an interaction between two persons, merely, but a series of transactions carried on in thickly peopled and complexly imaged contests" (1959, pp. 56-57) where everybody has a say in different, often conflicting, ways, co-creating the stories or thwarting them.

A case of being thwarted was mentioned in the interview with a 27 -yearold blogger from Saudi Arabia. She had written about racist incidents in her home town. Some readers of her blog were scandalized by that entry and asked her how she could presume to write about that topic and how she had the guts to do so. As a result, the blogger deleted her entry. The reactions of Others, she felt, had pointed out the limits to her narrative: "It kind of showed me the boundaries." In this example, it is the concrete Others who spoke out on the narrator's story, contributing to her deleting it.

There is yet another possibility for Others to influence a narrative in general, without becoming active as concrete Others. This proposition alludes to the concept of "the generalized other" (1934, p. 154), as George H. Mead phrases it. The "generalized other" represents the "organized community or social group," for example a sports team which the individual belongs to (1934, p. 154). It gains influence over the individual by "[his] taking the attitude of the generalized other toward himself" (1934, p. 156). Mead calls "the organized set of attitudes of others which one himself assumes" the "me," as opposed to the "I" (1934, p. 175). In order to flesh out the possible influence of this "me," I would like to return to the 27-year-old blogger from Saudi Arabia mentioned earlier. She might have deleted her post on racism in her home town even if there had not been any critical reactions, for example if she had dwelt on the taboos present in her society and had judged that she was putting herself at too great a risk.

The "I" responds to the social "me," according to Mead, embodying the autonomous power of the individual who is creative and capricious (1934, pp. 174ff.). In the "me," the community comes to the individual; with the response of the "I," the individual sounds out the limits of his (or her) room for manoeuvre. Kenneth Gergen criticizes Mead for assuming 
that individuals have little scope for independence, for considering that individuals think and act within purely social roles and, in this sense, for arguing in favour of social determinism (1999, pp. 124-125). Wolfgang Kraus, in turn, introduces the concept of negotiation, proposing that the relationship between the individual and society should be flagged as dialogic when it is a case of drawing attention to the contents and forms of narrating in the context of social processes $(2007$, p. 5$)$. This process of negotiation can also be anticipatory, according to Kraus, and can be conducted with an imaginary audience $(2007$, p. 5$)$. This suggestion mediates between the approaches proposed by Mead and Gergen.

A 26-year-old Yemeni blogger described such a process of negotiation in her interview when she talked about what she did or did not blog about. The topic of religion, for example, is taboo in her view: "If I do blog about religion I will be subject for death, that anybody can kill me." Initially she refused categorially to include religion as part of the narrative in her blog. But when she started to talk about the fact that the society in which she was living was in a state of transformation, her stance became patchy. She still refused to express her opinion on religious topics, but this refusal appeared to have a time limit, for she explained that "I don't think my people in my country is $[$ sic] ready enough now to hear about my views about religion or rituality, so this I would not write about now, but later." My interpretation of this statement is that it is still too early for such narratives. The "not now" in her last sentence signalizes an inner dialogue with an imaginary audience. The "not now" promises that, in her eyes, one day, something different will be possible, as expressed in the formulation "but later."

The idea of the Other as a co-narrator opposes the claim to autonomy in the modern age according to which autonomy is the result of dissociating oneself from Others. It makes it clear that choices relating to the autonomy of the subject do not happen outside relationships. Instead, the much more important question is whether and how autonomy can develop in and through relationships.

\subsubsection{The Other as Part of the Narrative Self}

What is the relationship of the co-narrator to the narrator? When George H. Mead writes that "there could not be an experience of a self simply by itself" (1934, p. 195), it is unclear whether he was thinking of the "I" and the Other as distinct entities or as being interconnected with each other. Mead also expresses this thought elsewhere in his book: 
No hard-and-fast line can be drawn between our own selves and the selves of others, since our own selves exist and enter as such into our experience only in so far as the selves of others exist and enter as such into our experience also. (1934, p. 164)

Mead's statements provoke thoughts as to the possibilities of the transcendence of the I. Despite the pronouncements quoted earlier, Mead himself, in Kenneth Gergen's eyes (1999, pp. 124-125), still aligned himself to the notion that subjects are born as separate individuals and also encounter each other as such.

Gergen, in contrast, espouses the concept of a "relational being." In this concept, "it is the individual who carries past dialogues into the present ... and is born afresh within ongoing dialogue" (1999, p. 131). As the term dialogue designates a communicative occurrence, which would include narratives, this suggests that Gergen's proposition of the relational being should also be taken into consideration in the context of narrative subject constructions. Karen Joisten confirms, at least, that humans are narratively composed from the start because they are "already integrated in the narrative context of a tradition at birth, which gives them support and orientation" (2007, p. 187). The integration proposed by Joisten amounts to an inevitable conjointness within which individuals become what they are. "Whatever we are," writes Gergen, "from the present standpoint, is either directly or indirectly with others. ... We are made up of each other" (1999, pp. 137-138).

This conjointness can take effect in biographical narratives as tension, as illustrated in the life story of a Japanese man (see also "Spaces as Products of Narrating" in Sect. 2.1.2.1), which Shingo Shimada presented in his essay "The Cultural Self-Culture in the Self." Born in 1930, Mr M embedded all of his life choices in the context of his social environment, depicting them as the result of his prudent dealings and compliance with the opinion of Others (Shimada, 2006, pp. 85-86). This integration of his own life history in the social context complies with the cultural specifications for a successful narrative presentation of the self in Shimada's eyes (2006, p. 86). From a Western perspective, the tension in this narrative is caused by Mr M being presented as a successful, self-confident businessman on the one hand and as somebody "who, individually, cannot take an autonomous decision" on the other (2006, p. 86). Shimada's explanation is that an individual's life story is not so much conceived of as an individual project but rather as a path which is integrated in an interpersonal network 
within which decisions are taken which are dependent on Others without this being perceived of as a lack of independence (2006, p. 90).

The tension between individuals and their social environment may take on a specific configuration in Japanese culture but it can also be observed in other cultures, as the example of a 26-year-old blogger who lives in a Western industrialized country shows. She talked about the way in which she ran her blog, saying that she did not always feel like blogging, if it were not for the Others, the readers of her blog. She felt duty-bound towards them; their expectations gave her a bad conscience; she even felt pressurized. As she put it, "[w]ow, you've not written anything for one and a half weeks yet again. Write something, won't you! It does put the pressure on me." The blogger's narrative shows that the way in which she runs her blog is also the result of the reaction of Others, whether real or presumed. She, too, is what she is in conjunction with others, although the given example only covers a small part of her life. For both narratives, Gergen's statement applies, namely that "we are mutually constituting" (1999, p. 138). There is, however, an important difference between the two narratives. Whereas the narrative about the Japanese businessman does not identify any discrepancies between the expectations of his social environment and the protagonist's decisions, the blogger refers to such discrepancies explicitly in her narrative, experiencing them as pressure, which she defers to, however, because she cannot do without the Others, the ones she reaches with her writing. She even admonished herself: "Now think, won't you, what you could write, otherwise they'll scarper."

There must be countless possibilities in which the Other can become part of the narrative Self, how narrators position themselves in their narratives in relation to this Other which is a part of themselves, how narrators experience the Other, and which actions the remembered or imagined Other incites the narrator to do. The controversial question remains, however, as to whether narrating opens up chances of freedom for the subject and, if so, which.

\subsection{Narrating as a Technology of Subjection AND ENABLEMENT}

In their narratives, people become aware of their past and present; they gain orientation and agency. Narrating helps them to anticipate the future and think of new perspectives, or to change; at the same time, narrating 
has an integrative effect as it connects things to one another. When we tell stories, we find ourselves; we experience ourselves as an I; we learn how to understand this I and to develop it further. In this sense, narrating serves to construct the Self.

Nevertheless, we are not alone when directing our own narratives. The Others also have a role to play, whether as points of reference, the topics of narratives, or as co-narrators; sometimes they even slip into the narrator's shoes, acting as part of the narrative Self. The Others are present as concrete Others, visible offline and invisible in the internet, but also as potential, imagined Others or as "the generalized other" (Mead, 1934, p. 154), present, in other words, as a collective stance or norm. The concrete or imagined Other which represents a You is not necessarily identical with "the generalized other" (1934, p. 154), which represents a norm.

What all of these different Others have in common is that they write themselves into our narratives. The Others are undeniably there; we cannot turn off their influence. Borrowing from the Italian philosopher, Adriana Cavarero (2000), Judith Butler writes "We cannot exist without addressing the other and without being addressed by the other" (2005, p. 33) and continues that "there is no wishing away our fundamental sociality" $(2005$, p. 33$)$. But we also have designs on these Others. Our narratives are aimed at the Others' gaze so that they turn towards us. It is recognition that we expect from this gaze. We experience this gaze as recognition because, as already described in Sect. 2.2.2.1. ("The Other as a Reference Point for Narrating”), it touches parts of us which remain hidden from ourselves and are only revealed to us in the resonance of this gaze (Meyer-Drawe, 1990, p. 116). We recognize ourselves in this gaze directed at us; through this gaze we achieve self-confidence and selfassurance (J. Benjamin, 1988, p. 21). Recognition in this sense does not pin down the status quo. On the contrary: Recognition initiates change. According to Butler, "recognition becomes the process by which I become other than what I was and so cease to be able to return to what I was" $(2005$, p. 27). In this sense, recognition promotes the development of the subject.

In order to achieve recognition, we have to make ourselves recognizable. The narrative is the medium which helps us in our attempt to establish recognizability. Provided that the Other is one of the Yous we want to be recognized by, we refer back to their expectations in our narratives, showing that we are taking these expectations seriously. These expectations can already include social norms which we cannot simply ignore in 
the interests of our recognizability. Butler posits that we have to make ourselves "to some degree ... substitutable" $(2005$, p. 37$)$ in the narrative account; in other words, we have to be like Others and follow the same rules as Others. The "singularity of my story" must make way for "the perspective and temporality of a set of norms" $(2005$, p. 37). The norms are indispensable, if recognition is to be possible, because yardsticks are required against which recognition can measure itself. Before recognition can exist, norms have to exist. To start with, these norms are not mine as their temporality is not the same as the temporality of my life. They precede the I, creating the stage on which the I orchestrates its recognizability through narrative. This I integrates itself with its narrations in the social rule book, proving to be dependent on sociocultural specifications (Reckwitz, 2008, p. 12).

Is it still possible to take this I as the actor in its narratives? Does it not rather have to be seen as an effect of social structures? From Judith Butler's standpoint, the I still has some leeway, despite its dependence (2005, p. 34). She refers to Adriana Cavarero, who "argues for an irreducibility to each of our beings that becomes clear in the distinct stories we have to tell" (2000, p. 89). That is why "any effort to identify fully with a collective 'we' will necessarily fail" (Butler, 2005, p. 34). Just what characterizes this irreducibility and how it can arise are revealed by the following train of thought, which is also derived from Butler's argumentation. It is based on the consideration that the ideas, expectations, and plans of the I are not co-extensive with the social norms which are in store for the I, as expectations, in certain situations. This discrepancy between the subject and norms could be based on the interplay between the genetic code and specific life experiences and events. When the I perceives the discrepancy, this means that it has to contemplate these norms, just like the blogger quoted earlier began to contemplate the discrepancy she had perceived between her rhythm of writing and the presumed expectations of the readers of her blog. This contemplation implies a relation between the I and social rules in which something can emerge which Butler, in line with Adorno, calls a "living appropriation" $(2005$, p. 7$)$, by which Adorno also understands a "critical examination" (1996, p. 35), or reflexivity. This reflexive relation to the rules poses the question 'What should I do?' which denotes critical dealings with the rules. Butler also sees the critical potential of appropriation in Foucault, whose intention it was to show "that social norms cannot bring forth the subject, without the subject articulating these norms reflexively in the form of ethics" $(2003$, p. 10). In relation to this 
proposition, the discrepancy with social norms is true for every I, so also for the I that the narrator encounters as the You. At the same time, every I that becomes a You confronts the other I with its own expectations.

Neither the expectations of the You nor the social norms have a deterministic effect. They "[set] the stage for the subject's self-crafting" (Butler, 2005 , p. 19). Integrating oneself in the social tradition in the medium of narrative does not merely happen as an adaptation of social specifications but as a critical convergence with a You or with social rules, with the goal of achieving recognition without having to give up on our uniqueness. According to literary theorist Homi $\mathrm{K}$. Bhabha in an interview with Lukas Wieselberg, even in the position of the underdog, there are "possibilities to upend imposed authorities, to accept some aspects, and reject others" (Bhabha, 2007). In their narratives, subjects lead a double life: They are simultaneously subservient and sovereign (Meyer-Drawe, 1990, p. 151). Narrating thus proves to be a technology of subjection and enablement alike.

\section{REFERENCES}

Adorno, T. W. (1996). Probleme der Moralphilosophie [Problems of moral philosophy]. Frankfurt am Main: Suhrkamp.

Ahrens, D. (2003). Die Ausbildung hybrider Raumstrukturen am Beispiel technosozialer Zusatzräume [The formation of hybrid spatial structures taking the example of supplementary technosocial spaces]. In C. Funken \& M. Löw (Eds.), Raum-Zeit-Medialität (pp. 173-190). Frankfurt am Main: Leske + Budrich.

Althans, B. (2000). Der Klatsch, die Frawen und das Sprechen bei der Arbeit [Gossip, women, and talking at work]. Frankfurt am Main: Campus.

Assmann, A. (1991). Fest und flüssig: Anmerkungen zu einer Denkfigur [Firm and fluid: Remarks on a figure of thought]. In A. Assmann \& D. Horth (Eds.), Kultur als Lebenswelt und Monument (pp. 181-199). Frankfurt am Main: Fischer Taschenbuch.

Barthes, R. (1988). The semiotic challenge (R. Howard, Trans.). Oxford: Blackwell. Benjamin, J. (1988). The bonds of love: Psychoanalysis, feminism, and the problem of domination. New York, NY: Pantheon Books.

Bhabha, H. K. (2007). Migration führt zu "bybrider" Gesellschaft [Migration leads to a "hybrid" society]. Retrieved from https://sciencevl.orf.at/science/ news/149988

Bilden, H. (2009). Das vielstimmige heterogene Selbst—ein prekäres Unterfangen: Subjektivität nach der Kritik am klassischen Subjektbegriff [The many-voiced 
heterogeneous self-an uncertain undertaking: Subjectivity after criticism of the classical concept of the subject]. Retrieved from http://www.helga-bilden. de/Artikel/Das_vielstimmige_heterogene_Selbst-Ein_prek\%E4res_ Unterfangen.html

Bourdieu, P. (1990). The logic of practice (R. Nice, Trans.). Stanford, CA: Stanford University Press. (Original work published 1980).

Bruner, J. (1990). Acts of meaning. Cambridge, MA: Harvard University Press.

Butler, J. (2003). Kritik der ethischen Gewalt [Against ethical violence; published in English as Giving an account of oneself]. Frankfurt am Main: Suhrkamp.

Butler, J. (2005). Giving an account of oneself. New York, NY: Fordham University Press.

Cavarero, A. (2000). Relating narratives: Storytelling and selfhood (P. A. Kottman, Trans.). London: Routledge.

Dickhardt, M., \& Hauser-Schäublin, B. (2003). Eine Theorie kultureller Räumlichkeit als Deutungsrahmen [A theory of cultural spatiality as an interpretive framework]. In B. Hauser-Schäublin \& M. Dickhardt (Eds.), Kulturelle Räume. Räumliche Kultur (pp. 13-43). Münster: LIT.

Ehrenberg, A. (2010). The weariness of the self: Diagnosing the history of depression in the contemporary age (E. Caouette, J. Homel, D. Homel, \& D. Winkler, Trans). Montreal: McGill-Queen's University Press. (Original work published 1998).

Foucault, M. (1979). Discipline and punish: The birth of the prison (A. Sheridan, Trans.). New York, NY: Vintage Books. (Original work published 1975).

Foucault, M. (1988). Technologies of the self. In L. H. Martin, H. Gutman, \& P. H. Hutton (Eds.), Technologies of the self: A seminar with Michel Foucault (pp. 16-49). Amherst, MA: The University of Massachusetts Press.

Foucault, M. (2005). The hermenentics of the subject: Lectures at the College de France 1981-1982 (G. Burchell, Trans.). New York, NY: Palgrave Macmillan. (Original work published 2001).

Gergen, K. J. (1999). An invitation to social construction. London: Sage.

Grimm, J., \& Grimm, W. (1984). Deutsches Wörterbuch [German dictionary]. (Vol. 3). Leipzig: S. Hirzel Deutscher Taschenbuchverlag. (Original work published 1862).

Hardy, B. (1968). Towards a poetics of fiction: An approach through narrative. Novel: A Forum on Fiction, 2(1), 5-14.

Helsper, W. (1997). Das 'postmoderne Selbst': Ein neuer Subjekt- und JugendMythos? Reflexionen anhand religiöser jugendlicher Orientierungen [The 'postmodern' self: A new myth of the subject and youth? Reflections on young people's religious orientations]. In H. Keupp \& R. Höfer (Eds.), Identitätsarbeit heute (pp. 174-206). Frankfurt am Main: Suhrkamp.

Herder, J. G. (2002). This too a philosophy of history for the formation of humanity (M. N. Forster, Trans.). In M. N. Forster (Ed.), Philosophical writings 
(pp. 272-358). Cambridge: Cambridge University Press. (Original work published 1774).

Hustvedt, S. (2003). What I loved. London: Sceptre.

Hustvedt, S. (2008). The sorrows of an American. London: Sceptre.

Hutton, P. H. (1988). Foucault, Freud, and the technologies of the self. In L. H. Martin, H. Gutman, \& P. H. Hutton (Eds.), Technologies of the self: $A$ seminar with Michel Foucault (pp. 121-144). Amherst, MA: The University of Massachusetts Press.

Joisten, K. (2007). Das 'narrative Selbst' und das Problem der Verantwortung in Alasdair MacIntryres Der Verlust der Tugend [The 'narrative self' and the problem of responsibility in Alasdair MacIntyre's After virtue: A study in moral theory]. In K. Joisten (Ed.), Narrative Ethik: Das Gute und das Böse erzählen; Deutsche Zeitschrift für Philosophie (Vol. 17, pp. 187-199). Berlin: Akademie.

Kraus, W. (2000). Identität als Narration: Die narrative Konstruktion von Identitätsprojekten [Identity as narration: The narrative construction of identity projects]. Retrieved from http://web.fu-berlin.de/postmoderne-psych/berichte $3 /$ kraus.htm

Kraus, W. (2007). Das narrative Selbst und die Virulenz des Nichterzählten [The narrative self and the virulence of what is not narrated]. In K. Joisten (Ed.), Narrative Ethik: Das Gute und das Böse erzählen; Deutsche Zeitschrift für Philosophie (Vol. 17, pp. 25-43). Berlin: Akademie.

Lacan, J. (1968). The language of the self: The function of language in psychoanalysis (A. Wilden, Trans.). Baltimore, MD: The Johns Hopkins University Press. (Original work published 1953).

Lacan, J. (1996). The function and field of speech and language in psychoanalysis (B. Fink in collaboration with H. Fink \& R. Grigg, Trans.). In J. Lacan (Ed.), Écrits (pp. 197-268). New York, NY: W. W. Norton. (Original work published 1953).

Langer, S. K. (1957). Philosophy in a new key: A study in the symbolism of reason, rite, and art (3rd ed.). Cambridge, MA: Harvard University Press.

Leontev, A. N. (2009). Activity, consciousness, and personality (M. J. Hall, Trans.). Marxists Internet Archive. Retrieved from https://www.marxists.org/archive/ leontev/works/1978/activity-consciousness-personality.pdf (Original work published 1978).

Liessmann, K. P. (2006). Theorie der Unbildung [The theory of miseducation]. Vienna: Paul Szolny.

Lorenzer, A. (1981). Das Konzil der Buchbalter [The council of the bookkeepers]. Frankfurt am Main: Europäische Verlagsanstalt.

Mahne, N. (2006). Mediale Bedingungen des Erzäblens im digitalen Raum: Untersuchungen narrativer Darstellungstechniken der Hyperfiktion im Vergleich zum Roman [Media conditions for narrating in digital space: Studies on narra- 
tive techniques of representation in hyperfiction in comparison with the novel]. Frankfurt am Main: Peter Lang.

Mannheim, K. (1964). Wissenssoziologie [The sociology of knowledge]. Berlin: Luchterhand

Maresch, R., \& Werber, N. (2002). Permanenzen des Raums [Permanences of space]. In R. Maresch \& N. Werber (Eds.), Raum, Wissen, Macht (pp. 7-32). Frankfurt am Main: Suhrkamp.

Mead, G. H. (with Morris, C. W., Ed.). (1934). Mind, self and society: From the standpoint of a social behaviorist. Chicago, IL: The University of Chicago Press.

Meuter, N. (1995). Narrative Identität: Das Problem der personalen Identität im Anschluss an Ernst Tugendhat, Niklas Lubmann und Paul Ricour [Narrative identity: The problem of personal identity following Ernst Tugendhat, Niklas Luhmann, and Paul Ricœur]. Stuttgart: Verlag für Wissenschaft und Forschung der J.B. Metzlerschen Verlagsbuchhandlung and Carl Ernst Poeschel Verlag.

Meyer-Drawe, K. (1990). Illusionen von Autonomie [Illusions of autonomy]. München: P. Kirchheim.

Mullican, M. (with Wilmes, U., Ed.). (2011). Im Gespräch/Conversations mit/ with Koen Brams, Dirk Pültau. Köln: DuMont.

Neumann, M. (2000). Erzählen: Einige anthropologische Überlegungen [Narrating: Some anthropological considerations]. In M. Neumann (Ed.), Erzählte Identitäten: Ein interdisziplinäres Symposium (pp. 280-294). München: Wilhelm Fink.

Nussbaum, M. (1990). Aristotelian social democracy. In R. B. Douglass, G. M. Mara, \& H. S. Richardson (Eds.), Liberalism and the good (pp. 203-252). New York, NY: Routledge.

Porschen, S., \& Böhle, F. (2005). Geschichten-Erzählen im Arbeitsalltag: Story Telling und erfahrungsgeleitete Kooperation [Telling stories in everyday work: Storytelling and experience-based cooperation]. In G. Reimann (Ed.), Erfahrungswissen erzählbar machen: Narrative Ansätze für Wirtschaften (pp. 52-67). Lengerich: Papst Science.

Pritsch, S. (2008). Rhetorik des Subjekts: Zur textuellen Konstruktion des Subjekts in feministischen und anderen postmodernen Diskursen [Rhetoric of the subject: On the textual construction of the subject in feminist and other postmodern discourses]. Bielefeld: transcript.

Quasthoff, U. M. (1980). Gemeinsames Erzählen als Form und Mittel im sozialen Konflikt oder Ein Ehepaar erzählt eine Geschichte [Telling stories together as a form and medium in social conflict: Or a married couple tells a story]. In K. Ehlich (Ed.), Erzüblen im Alltag (pp. 109-141). Frankfurt am Main: Suhrkamp.

Reckwitz, A. (2008). Subjekt [Subject]. Bielefeld: transcript. 
Ricour, P. (1985). Time and narrative: The configuration of time in fictional narrative (Vol. 2, K. McLaughlin \& D. Pellauer, Trans). Chicago, IL: The University of Chicago Press.

Ricour, P. (2005). The course of recognition (D. Pellauer, Trans). Cambridge, MA: Harvard University Press.

Rivera, M. (2002). Linking the psychological and the social: Feminism, poststructuralism, and multiple personality. In M. Dimen \& V. Goldner (Eds.), Gender in psychoanalytic space: Between clinic and culture (pp. 331-351). New York, NY: Other Press.

Roth-Ebner, C. (2015). Der effiziente Mensch: Zur Dynamik von Raum und Zeit in mediatisierten Arbeitswelten [The efficient person: On the dynamics of space and time in mediatized work environments]. Bielefeld: transcript.

Schutz, A. (1967). The phenomenology of the social world (G. Walsh \& F. Lehnert, Trans.). Evanston, IL: Northwestern University Press. (Original work published 1932).

Schutz, A., \& Luckmann, T. (1974). The structures of the life-world (R. M. Zaner \& H. T. Engelhardt, Jr., Trans.). London: Heinemann.

Sennett, R. (1998). The corrosion of character: The personal consequences of work in the new capitalism. New York, NY: W. W. Norton.

Shimada, S. (2006). Das kulturelle Selbst-die Kultur im Selbst: Eine Skizze [The cultural self-culture in the self: A sketch]. Journal für Psychologie: Theorie, Forschung, Praxis, 14, 76-92.

Simmel, G. (1997). The sociology of space (M. Ritter, \& D. Frisby, Trans.). In D. Frisby \& M. Featherstone (Eds.), Simmel on culture: Selected writings (pp. 137-169). London: Sage. (Original work published 1903).

Simmel, G. (2009). Sociology: Inquiries into the construction of social forms (Vol. 2, A. J. Blasi, A. K. Jacobs, \& M. J. Kanjirathinkal, Eds. \& Trans.). Leiden: Brill. (Original work published 1922).

Strauss, A. L. (1959). Mirrors and masks: The search for identity. Glencoe, IL: The Free Press.

Studiverzeichnis. (n.d.). Retrieved from http://www.studivz.net

SWR Kindernetz. (2020). Retrieved from www.kindernetz.de

Taylor, C. (1991). Language and society (J. Gaines \& D. L. Jones, Trans.). In A. Honneth \& H. Joas (Eds.), Communicative action (pp. 23-35). Cambridge: Polity. (Original work published 1986).

Waldenfels, B. (2001). Unerzählbares [Non-narratable]. In J. Trinks (Ed.), Möglichkeiten und Grenzen der Narration (pp. 19-38). Wien: Turia + Kant.

Welsch, W. (1991). Subjektsein heute: Überlegungen zur Transformation des Subjekts [Being a subject today: Reflections on the transformation of the subject]. Deutsche Zeitschrift für Philosophie, 4, 347-365.

Welsch, W. (2001). Auf dem Weg zur transkulturellen Gesellschaft [Heading for a transcultural society]. Paragrana, 10(2), 254-284. 
Wittgenstein, L. (1953). Philosophische Untersuchungen: Philosophical investigations (G. E. M. Anscombe, Trans.). Oxford: Blackwell.

Zoll, R. (1993). Lebenswelt im Umbruch: Bemerkungen zu den Veränderungen der Lebenswelt im Osten und Westen Deutschlands [Life-world in upheaval: Observations on changes in the life-world in East and West Germany]. Unpublished manuscript, Department of Sociology, University of Bremen.

Open Access This chapter is licensed under the terms of the Creative Commons Attribution 4.0 International License (http://creativecommons.org/licenses/ by $/ 4.0 /)$, which permits use, sharing, adaptation, distribution and reproduction in any medium or format, as long as you give appropriate credit to the original author(s) and the source, provide a link to the Creative Commons licence and indicate if changes were made.

The images or other third party material in this chapter are included in the chapter's Creative Commons licence, unless indicated otherwise in a credit line to the material. If material is not included in the chapter's Creative Commons licence and your intended use is not permitted by statutory regulation or exceeds the permitted use, you will need to obtain permission directly from the copyright holder.

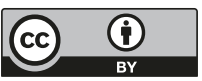

